\title{
Spatial distribution of living coccolithophores in the southwestern Gulf of Mexico
}

\author{
KARL-HEINZ BAUMANN ${ }^{1 *}$ \& BABETTE BOECKEL ${ }^{1,2}$ \\ ${ }^{1}$ Department of Geosciences, University of Bremen, PO Box 330440, 28334 Bremen, Germany \\ ${ }^{2}$ Present address: RWE Dea AG, Wietze Laboratory, Geosciences, Industriestr. 2, 29323 Wietze, Germany \\ *Corresponding author (e-mail: baumann@uni-bremen.de)
}

\begin{abstract}
The present study was conducted to provide information about the upper water column distribution of living coccolithophores in the subtropical Gulf of Mexico. In total, 52 plankton samples from 6 stations collected in March 2006 were analysed. Coccolithophore standing crops range from zero in deepwater samples $(200 \mathrm{~m})$ to about 23000 to 46500 coccospheres per litre at intermediate water depths. From 39 identified taxa, only nine species contribute significant cell numbers of more than 1000 cells $1^{-1}$ and comprise more than $5 \%$ of the communities in at least one sample. Emiliania huxleyi was the most abundant species throughout the stations with concentrations of up to 22700 cells $1^{-1}$. At all stations, a vertical succession of coccolithophore species was found. Umbellosphaera tenuis (type IV), Discosphaera tubifera, Rhabdosphaera clavigera and, as a minor component, species of the genus Syracosphaera, were mainly restricted to surface waters $(\leq 50 \mathrm{~m})$, all adapted to lower nutrient levels. The assemblage in the deep photic zone (50$150 \mathrm{~m}$ water depth) was composed mainly of abundant Florisphaera profunda, Gladiolithus flabellatus and Algirosphaera robusta indicating a tolerance of lower light availability. Thus, the vertical distribution of all coccolithophorid taxa, except the placolith-bearing species, in particular E. huxleyi, was probably controlled by upper photic-zone water temperature and stratification of the water column. J. Micropalaeontol. 32(2): 123-133, July 2013.
\end{abstract}

KEYWORDS: coccolithophores, living, ecology, Gulf of Mexico

\section{INTRODUCTION}

The Gulf of Mexico (GoM) has been the focus of numerous physical oceanographic studies (e.g. Vidal et al., 1994; Sturges \& Leben, 2000; Sturges \& Lugo-Fernandez, 2005; Zavala-Hidalgo et al., 2006), but relatively little is still known about the biological oceanography of the region (e.g. Müller-Karger et al., 1991). In addition, most biological oceanographic studies in the GoM have been geographically restricted (e.g. Ortner et al., 1984; Biggs \& Müller-Karger, 1994), and many of these studies have concentrated in the northern GoM. Here, high production rates and large stocks of phytoplankton, mainly dominated by diatoms, raphidophytes and dinoflagellates, are commonly observed in discharge plumes of the Mississippi and other river-dominated estuaries (e.g. Lohrenz et al., 1990; Dagg, 1995; Strom \& Strom, 1996; Livingston, 2007). They occur because riverine waters, which are turbid but rich in nutrients, become ideal for high rates of phytoplankton growth when they spread out over the receiving oceanic waters. Studies from the southern and southwestern GoM have also been conducted on various ecological aspects of phytoplankton and primary productivity (e.g. Okolodkov, 2003; HernándezBecerril et al., 2008). Many of these studies have traditionally considered the microplankton fraction, especially large diatoms and dinoflagellates, as the main contributors to primary production (e.g. Hernández-Becerril \& Flores, 1998; Licea et al. 2004, Hernández-Becerril et al., 2008).

Records of living coccolithophores from the GoM have been scarce so far. Gaarder \& Hasle (1971) qualitatively documented the coccolithophore communities from 12 surface water samples. Hulburt \& Corwin (1972) found planktonic flora in the southern GoM dominated by Emiliania huxleyi and Gephyrocapsa oceanica together with diatom species. Living coccolithophore communities from cruises in October 1990 and March 1991 in the northern GoM were analysed by Pariente (1997) but her observations basically were available only via internet (http://ocean.tamu.edu/Quarterdeck/ QD5.2/qdhome-5.2.html). This author concentrated on the coccolithophores inside and outside of eddies that spin off the warm current that enters the gulf through the Yucatan Strait. Basic results were that different species live in different layers of this photiczone 'house'. Most residents of the shallow layer belong to the tropical Umbellosphaera irregularis. The dominant species in the middle layer was Umbellosphaera tenuis and in the deepest, nutrient-rich layer it was Florisphaera profunda. The occurrence at rather shallow depth outside eddies of the latter species is, however, rather conspicuous in comparison to numerous other studies, in which $F$. profunda is usually documented below $100 \mathrm{~m}$ of water depth. Furthermore, coccolithophores were also found to play an important role in the structure of the phytoplankton communities in the southern GoM (Bay of Campeche). The highest phytoplankton abundance was dominated mainly by the species E. huxleyi and $G$. oceanica and was associated with a thermal front in the coastal shelf zone (Hernández-Becerril et al., 2008).

Not only is the GoM a special setting in terms of basin morphology and ventilation, but it offers also a unique living environment due to the presence of hydrocarbon seep features, so-called 'asphalt volcanoes', discovered in the deep Bay of Campeche in the southwestern GoM (MacDonald et al., 2004). The asphalt volcanoes are partly oversaturated with methane and higher hydrocarbons, which results in the formation of gas hydrates (Klapp et al., 2010), which may be a significant contributor to marine methane emissions. The hydrocarbon seepage also influences the uppermost water column by the escape of gas bubbles, and oil-coated gas bubbles. While sailing in the area during Meteor cruise M67/2a oil drops and oil slicks could be observed directly on the sea surface (Bohrmann et al., 2008) although no quantitative data are available on this. Since such anomalous occurrences are likely documented from the fossil record, the reinterpretation of their 


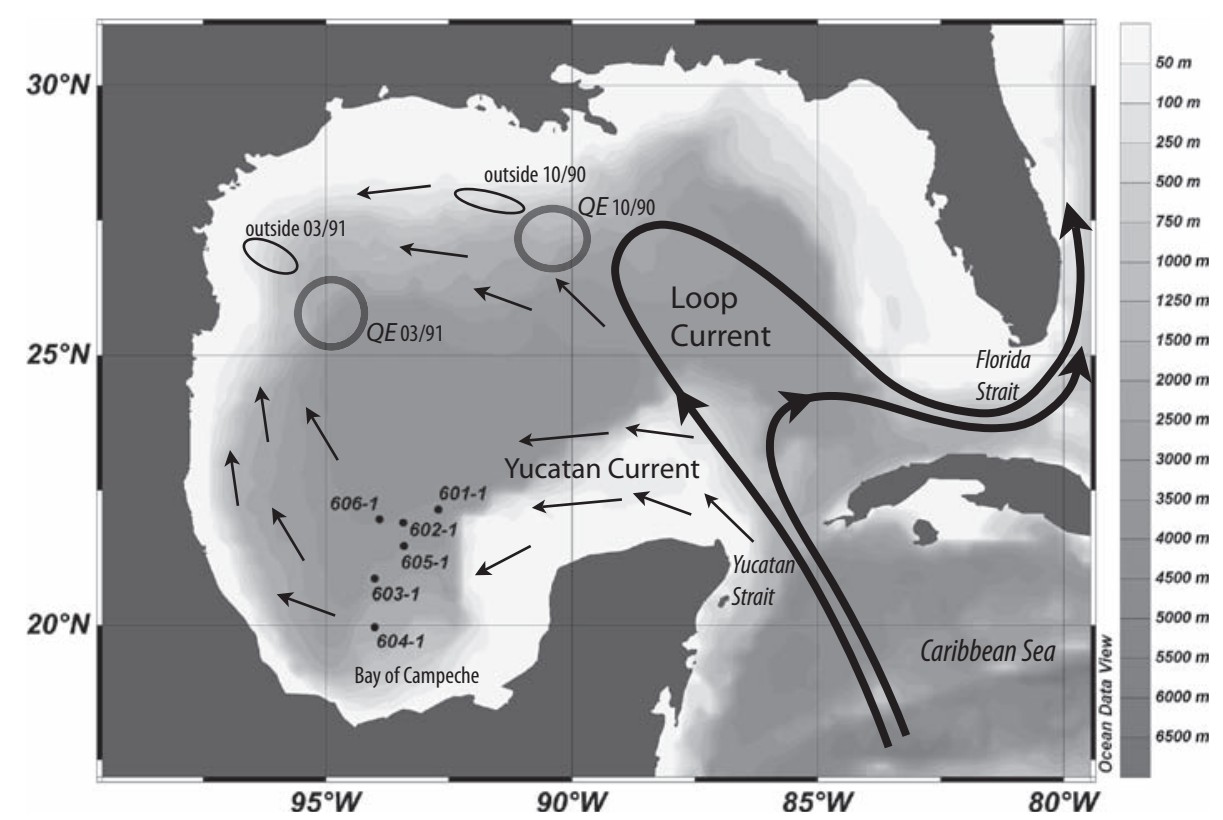

Fig. 1. Schematic map of the main surface water circulation in the upper level of the southern Gulf of Mexico (redrawn mainly from Gyory et al. n.d.). Locations of the studied water stations are indicated as black dots (full station codes are GeoB 10xxx-x; see also Table 1). In addition, areas of the samples of Pariente (1997) are indicated, including sampling stations inside Quiet Eddy (QE) and outside the eddy.

ecologies may also have significant impact on Quaternary nannofossil studies. However, assessing direct and indirect impacts of oil and dispersants on the marine pelagic ecosystem in the GoM requires sustained observations over multiple years.

Therefore, the aims of this study were: (1) to investigate the coccolithophorid species composition in a NE-SW transect with only slight contrast in hydrographic conditions; (2) to examine and correlate the species occurrences to available hydrographic data in order to add information on the habitat preferences of the species; and finally (3) to study the depth distribution of the species in this oceanic regime.

\section{MODERN OCEANOGRAPHY OF THE STUDY AREA}

The Gulf of Mexico is a marginal sea that is connected to the Atlantic Ocean via the Straits of Florida and to the Caribbean Sea via the Yucatan Strait. The main sea-surface currents of this area are summarized in a relatively comprehensive web-based ocean current reference site by Gyory et al. (n.d.; http://oceancurrents. rsmas.miami.edu/index.html; Fig. 1) and by Sturges \& LugoFernandez (2005).

In general, warm tropical waters from the Caribbean Sea enter the GoM through the Yucatan Strait, turn in a clockwise direction, 'loop' around a warm 'dome' of GoM surface water, and exit through the Florida Strait as one of the sources of the Gulf Stream. This anticyclonic gyre, called the Loop Current (LC; e.g. Sturges \& Evans, 1983), occupies the central portion of the gulf and is fed by the river-like Yucatan Current (YC) that flows through the narrow passage of the Yucatan Strait and provides most of the inflow into the GoM, since inflows through the Florida Straits are small and episodic (e.g. Lee \& Mayer, 1977; Ochoa et al., 2001). During summer, surface-water flow through the Yucatan Channel is enhanced compared to winter (Sheinbaum et al., 2002), and warm tropical surface temperatures occur in the western and northern gulf (Brunner, 1982). During winter the LC is at a minimum (e.g. Molinari et al., 1990; Johns et al., 2002) and follows a relatively direct path from the Yucatan Channel to the Florida Straits, thus leaving the northern GoM relatively unaffected by warm surface water from the Caribbean. Tropical waters from the Caribbean are restricted in winter to a narrow band in the southeastern gulf, reflecting the flow of the LC from the Yucatan Channel directly to the Florida Strait. Portions of the LC often break off from the main stream forming eddies or small gyres which move clockwise into the northeastern part of the gulf affecting regional current patterns (Sturges \& Leben, 2000; Zavala-Hidalgo et al., 2006). In addition, upwelling is described in the Yucatan region, probably as a result of interactions between the YC and the counter-current (Merino, 1997).

In the southwestern GoM, surface water circulation generally proceeds, as the YC, from the Yucatan Strait westward (Fig. 1) and then, as the Mexican Current, north along the western boundary of the basin (e.g. Molinari \& Morrison, 1988). These currents are relatively weak, varying appreciably in intensity with season and location. There is extreme variability in both current direction and speed on the continental shelf and in the coastal waters of the gulf, where currents are subjected to seasonal and annual variations caused not only by major circulation patterns but also by changes in the prevailing wind direction. In addition, smaller wind-driven and tidal currents are created in near-shore environments.

Generally, the surface mixed layer in the GoM is as shallow as $90 \mathrm{~m}$ in winter and $125 \mathrm{~m}$ during summer. Surface-water temperatures range from $18^{\circ} \mathrm{C}$ to $21^{\circ} \mathrm{C}$ in the north and $24^{\circ} \mathrm{C}$ to $27^{\circ} \mathrm{C}$ in the south while surface salinity values for this marginal sea generally range between 36.0 and 36.3 (e.g. Vidal et al., 1994). In the northern Gulf of Mexico region, Mississippi River runoff influences surface waters as far as $50 \mathrm{~km}$ from the shore, 
resulting in salinities as low as 25. Variation in sea-surface temperature (SST) is synchronous throughout the gulf, with maxima in July to September and minima in February to March (MüllerKarger et al., 1991). Surface pigment concentrations also follow a seasonal cycle, with very low concentrations $\left(<0.1 \mathrm{mg} \mathrm{m}^{-3}\right)$ from April through summer and slightly higher concentrations $\left(>0.18 \mathrm{mg} \mathrm{m}^{-3}\right)$ in winter (e.g. Müller-Karger et al., 1991; Biggs \& Müller-Karger, 1994)

\section{MATERIAL AND METHODS}

Fifty-two water samples were taken during Meteor Cruise M67/2 in 2006 (Table 1) using a Rosette sampler attached to a Conductivity Temperature Depth (CTD) device at 6 stations from distinct water depths (generally at $10 \mathrm{~m}, 20 \mathrm{~m}, 50 \mathrm{~m}, 75 \mathrm{~m}, 100 \mathrm{~m}$, $120 \mathrm{~m}, 150 \mathrm{~m}$ and $200 \mathrm{~m}$ ). Additional surface-water samples from $5 \mathrm{~m}$ water depth were taken from the vessel's membrane pump at all stations. Generally, 21 of water were filtered through cellulose nitrate filters ( $25 \mathrm{~mm}$ diameter, $0.45 \mu \mathrm{m}$ pore size) by means of a vacuum pump immediately onboard. Samples were rinsed with freshwater to avoid the precipitation of salt crystals. The filters were dried at $40^{\circ} \mathrm{C}$ for at least $24 \mathrm{~h}$, stored in plastic Petri dishes, and kept permanently dry with silica gel in transparent film.

For analysis, a piece of the dried filter was fixed with doublesided adhesive tape to an aluminium stub, sputter coated with gold-palladium and examined in a ZEISS DSM 940A scanning electron microscope (SEM), usually at $10 \mathrm{kV}$. Coccospheres were identified and counted on measured transects at $\times 3000$ magnification. Generally, it was aimed to count at least 200 specimens per filter; however, fewer were counted in the deepest samples, due to extremely low coccolithophore numbers. Coccolithophore cell densities were calculated as follows:

$$
\begin{aligned}
& \text { Coccolithophore concentration } \\
& \left(\text { no. of cells } 1^{-1}\right)=\frac{F \times C}{A \times V}
\end{aligned}
$$

with $F=$ filtration area $\left(\mathrm{mm}^{2}\right) ; C=$ number of counted coccolithophores; $A=$ counted area $\left(\mathrm{mm}^{2}\right)$; and $V=$ filtered water volume (1).

For analysis of modern diversity we generally used the taxonomy of Young et al. (2003). This is a suitable basis both because it is the most recent review and because it attempts to be comprehensive, including both formally described species, and many informally described morphotypes, which we regard as almost certainly genuine species. All identified species are listed alphabetically with full citations in Appendix A.

\section{RESULTS}

\section{Cell density and species diversity of total} coccolithophores

Coccolithophores were found in all of the studied samples, except for two deep samples $(200 \mathrm{~m})$ at stations GeoB 10602 and GeoB 10605 (Fig. 2). A total of 39 taxa were identified in this study (see Appendix A and Plate 1), with nine species reaching abundances of more than 1000 cells $1^{-1}$ and representing more than $10 \%$ of the communities in at least one sample. Due to a relatively high diversity and low cell numbers several species could not be shown individually for the sake of clarity and comparability between the samples but all taxa of importance are either depicted in the figures or mentioned in the text.

At all sites low abundance coccolithophore communities were found at the upper surface with numbers of $<25000$ cells $1^{-1}$ (Fig. 2). It is, however, noticeable that higher diversity, up to 20 species per sample, was reached within these upper water samples (down to $20 \mathrm{~m}$ ) than the samples with maximum total coccolithophore numbers. Highest numbers of no more than 48000 cells $1^{-1}$ were generally reached in intermediate water depths $(50-75 \mathrm{~m})$, except at station GeoB 10604, where highest numbers (23 700 cells $1^{-1}$ ) occurred at $120 \mathrm{~m}$ water depth. However, total coccolithophore numbers exceeded 28000 cells $1^{-1}$ only in intermediate depths of the two stations GeoB 10603 and GeoB 10606. And at stations GeoB 10602 and GeoB 10605, only rather low coccolithophore cell numbers of $<7000$ cells $1^{-1}$ are found in intermediate depths ( $75 \mathrm{~m}$ and $50 \mathrm{~m}$, respectively; Fig. 2).

Below about 75-100 m, a deep-photic nannoplankton community with total coccolithophore numbers of $<21000$ cells $1^{-1}$ and a relatively low diversity of less than 10 species per sample occurred. None the less, except for the deepest samples recovered $(200 \mathrm{~m})$, the total cell numbers were often comparable to those in the upper water column.

\section{Distribution of coccolithophorid assemblages and species}

The stations exhibit rather comparable assemblage compositions, with Emiliania huxleyi being the most abundant species in many of the samples throughout the water column (generally 20-65\%). This species reached highest numbers in the mid-depth of stations GeoB 10603/06 (Figs 2, 3). In addition, 14 species of the family Syracosphaeraceae occur from the surface water down to about $100 \mathrm{~m}$, with cell densities of up to 2500 cells $1^{-1}$ (up to $10 \%$ ) especially in station GeoB 10606. From these, eight species of Syracosphaera (excluding those occurring in the holococcolithophore stages) have been identified, but only S. pulchra occurs constantly and shows a clear abundance pattern. In addition, Gephyrocapsa oceanica and G. ericsonii were observed rather constantly in many of the samples but in low cell numbers of $<1000$ cells $1^{-1}$ (and thus are not shown separately here).

In all shallow-water samples coccolithophore assemblages are dominated by Umbellosphaera tenuis, forming $>30 \%$ of the assemblages, except at station GeoB 10602 (max. 28\%). This species mainly occurs in the upper $50 \mathrm{~m}$ of the water column but is also observed at greater depths $(100$ to $150 \mathrm{~m})$ at stations GeoB 10604-06 (Fig. 2). Surprisingly, U. irregularis appears only in very low numbers and in very few samples. In addition to U. tenuis, Discosphaera tubifera ( $>15 \%$ in the uppermost $20 \mathrm{~m}$ of stations GeoB 10601-04) and Rhabdosphaera clavigera (5-10\% in the uppermost $50 \mathrm{~m}$ of all stations) commonly contribute to the upper-water community with up to 4000 cells $1^{-1}$ and 3500 cells $1^{-1}$, respectively (Fig. 2). Other species, such as $S$. pulchra (up to 1000 cells $1^{-1}$ ), other Syracosphaera spp., and most of the observed holococcolithophores (up to 1400 cells $1^{-1}$ ) also contribute to the umbelliform-dominated assemblages in the uppermost $50 \mathrm{~m}$ of the water column.

A change in the predominant species occurs at intermediate water depths. The flora in the deep photic zone $(>50-150 \mathrm{~m}$ water depth) is characterized by abundant Florisphaera profunda (up to $62 \%$ ) in this nutrient-depleted part of the GoM (Fig. 2). 


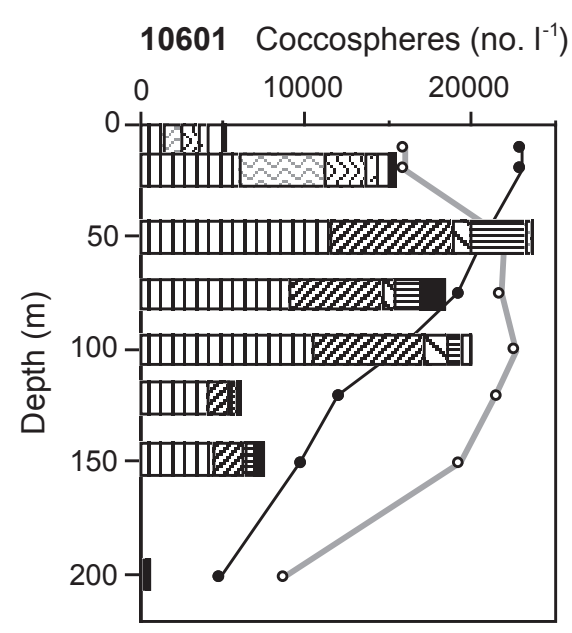

10602 Coccospheres (no. $I^{-1}$ )
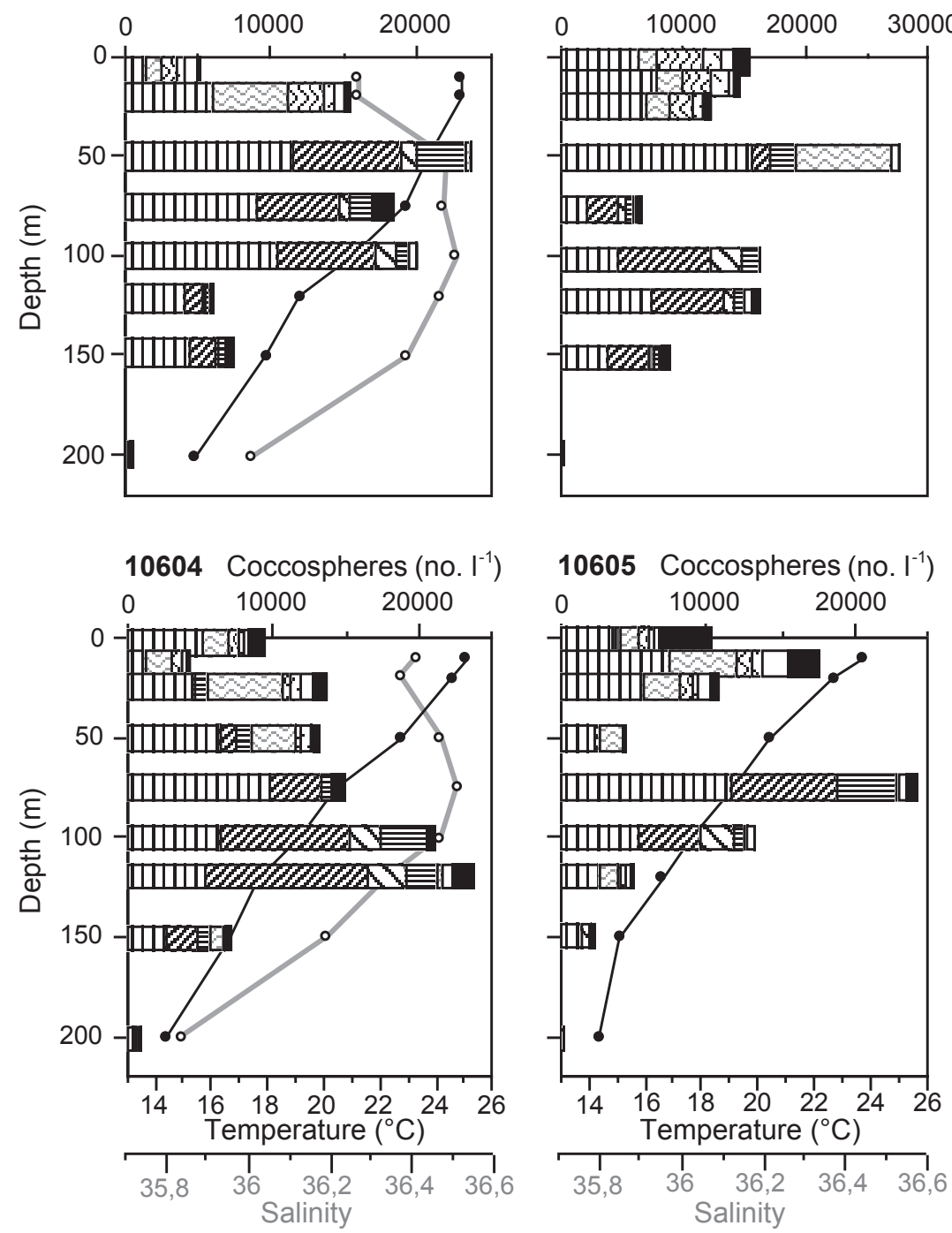

10605 Coccospheres (no. $\mathrm{I}^{-1}$ )

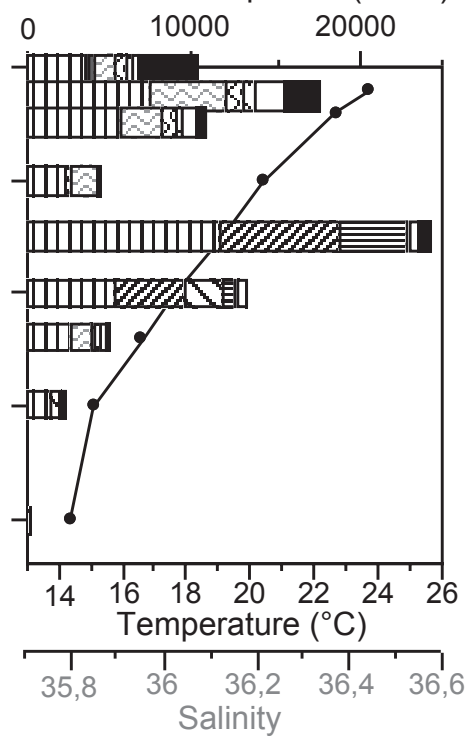

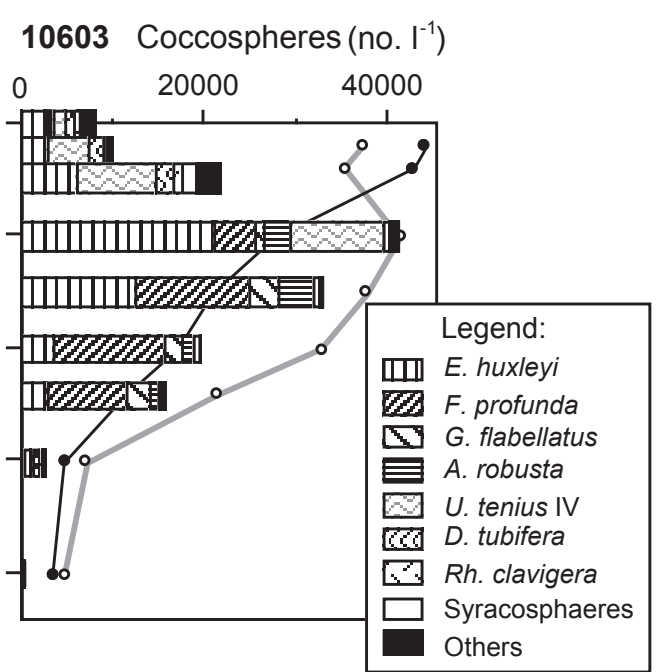

10606 Coccospheres (no. ${ }^{-1}$ )

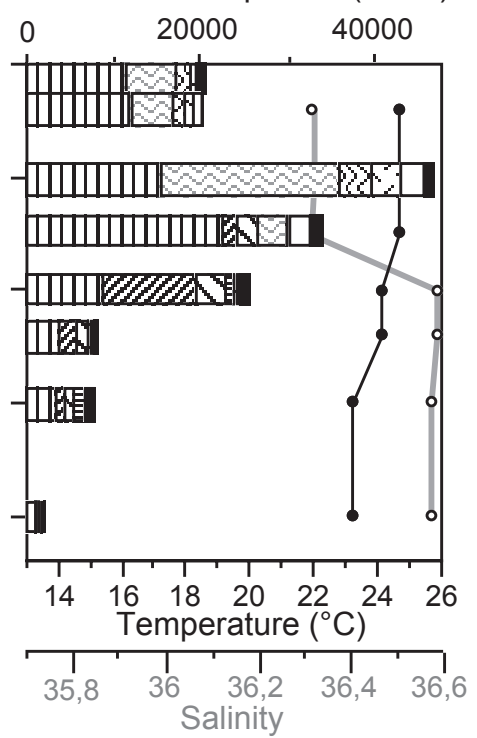

Fig. 2. Coccolithophore data for the investigated sites with profiles of temperature and salinity (if available). Additionally, the diversity is exhibited for all profiles.

Table 1. Locations and data of the investigated samples for coccolithophore analysis.

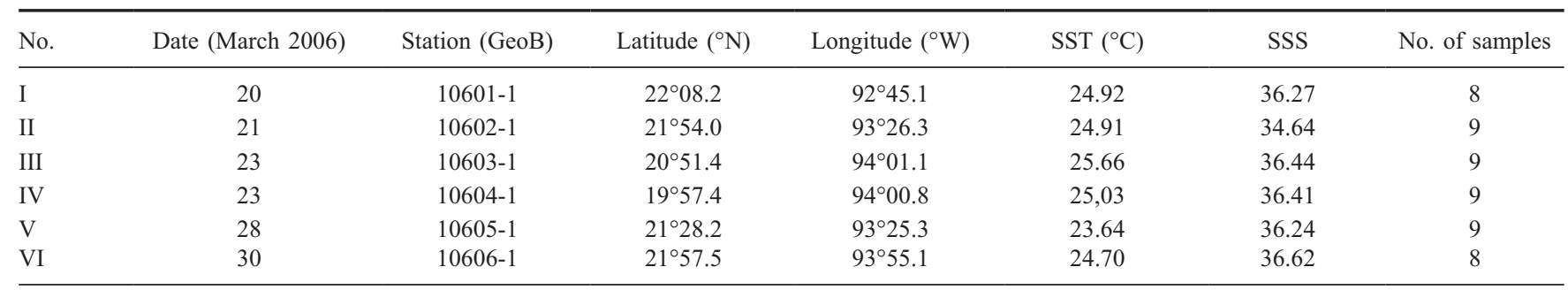

However, the change in predominance from the umbelliform flora of the upper photic zone to this deep photic zone flora occurs between either $50 \mathrm{~m}$ (GeoB 10601) or $100 \mathrm{~m}$ (GeoB10606) water depth. In addition, Gladiolithus flabellatus (up to $18 \%$ ) and Algirosphaera robusta (up to $16 \%$ ) are common components of this deep-photic flora.

Most of the other species observed in the samples exhibit very low coccolithophore cell numbers and occur only in a few samples. Scans of the filters also yielded the presence of some unexpected species, such as Reticulofenestra sessilis in association with diatoms and Coccolithus braarudii (Plate 1); the latter has so far been found mostly in temperate upwelling areas. There were also some unique scale-bearing protists of the order Rotosphaerida, i.e. Pinaciophora sp., which have so far been considered of uncertain systematic position (J.R. Young, pers. comm.). 


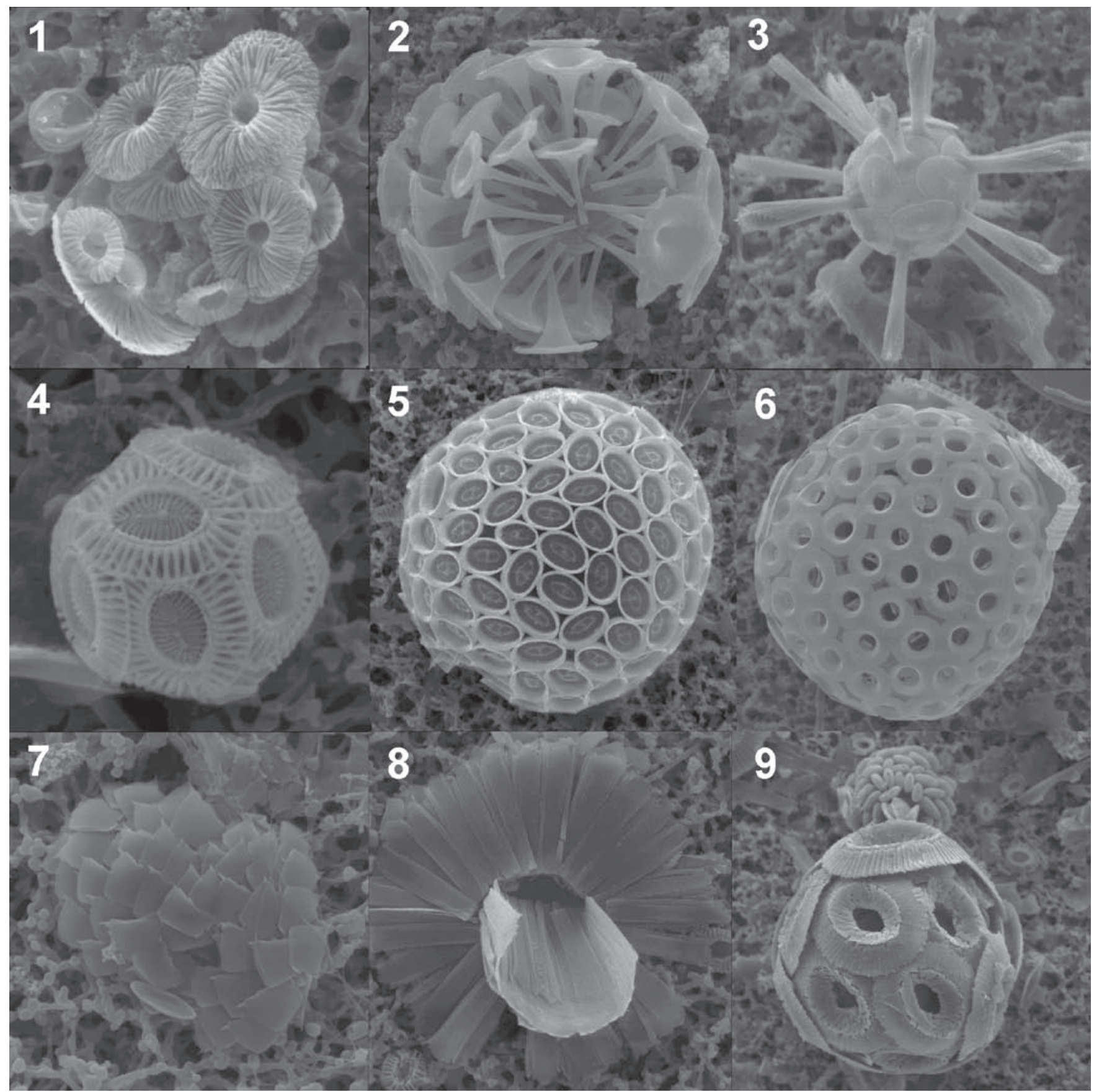

Explanation of Plate 1. Overview of the dominant coccolithophore species in the present M67/2 plankton samples. 1, Umbellosphaera tenuis (type VI), GeoB 10601, 20 m; 2, Discosphaera tubifera, GeoB 10601, 20 m; 3, Rhabdosphaera clavigera, GeoB 10603, 20 m; 4, Emiliania huxleyi (type A), GeoB 10601, 75 m; 5, Coronosphaera maxima, GeoB 10604, 75 m; 6, Umbilicosphaera sibogae, GeoB 10601, 50 m; 7, Florisphaera profunda (type rhinoceros), GeoB 10605, 75 m; 8, Gladiolithus flabellatus, GeoB 10604, $120 \mathrm{~m} ; \mathbf{9}$, Coccolithus braarudii and Algirosphaera robusta, GeoB $10601,75 \mathrm{~m}$.

\section{DISCUSSION}

\section{Coccolithophorid depth distribution}

The total of 39 taxa identified in this study with generally low cell numbers points to an open ocean community structure with stable environmental conditions (e.g. Andruleit et al., 2003; Andruleit, 2007; Boeckel \& Baumann, 2008). At all stations typical depth-related assemblages can be identified from the depth distribution of the species, although the deeper photic zone was not studied in high resolution. Two main assemblages occur: an upper photic zone (UPZ) assemblage and the typical lower photic zone (LPZ) assemblage. In addition, highest numbers reached in intermediate water depths (50-75 m, Fig. 3) are due mainly to increased cell numbers of Emiliania huxleyi and, to a much lesser extent, to species of the genus Syracosphaera as 


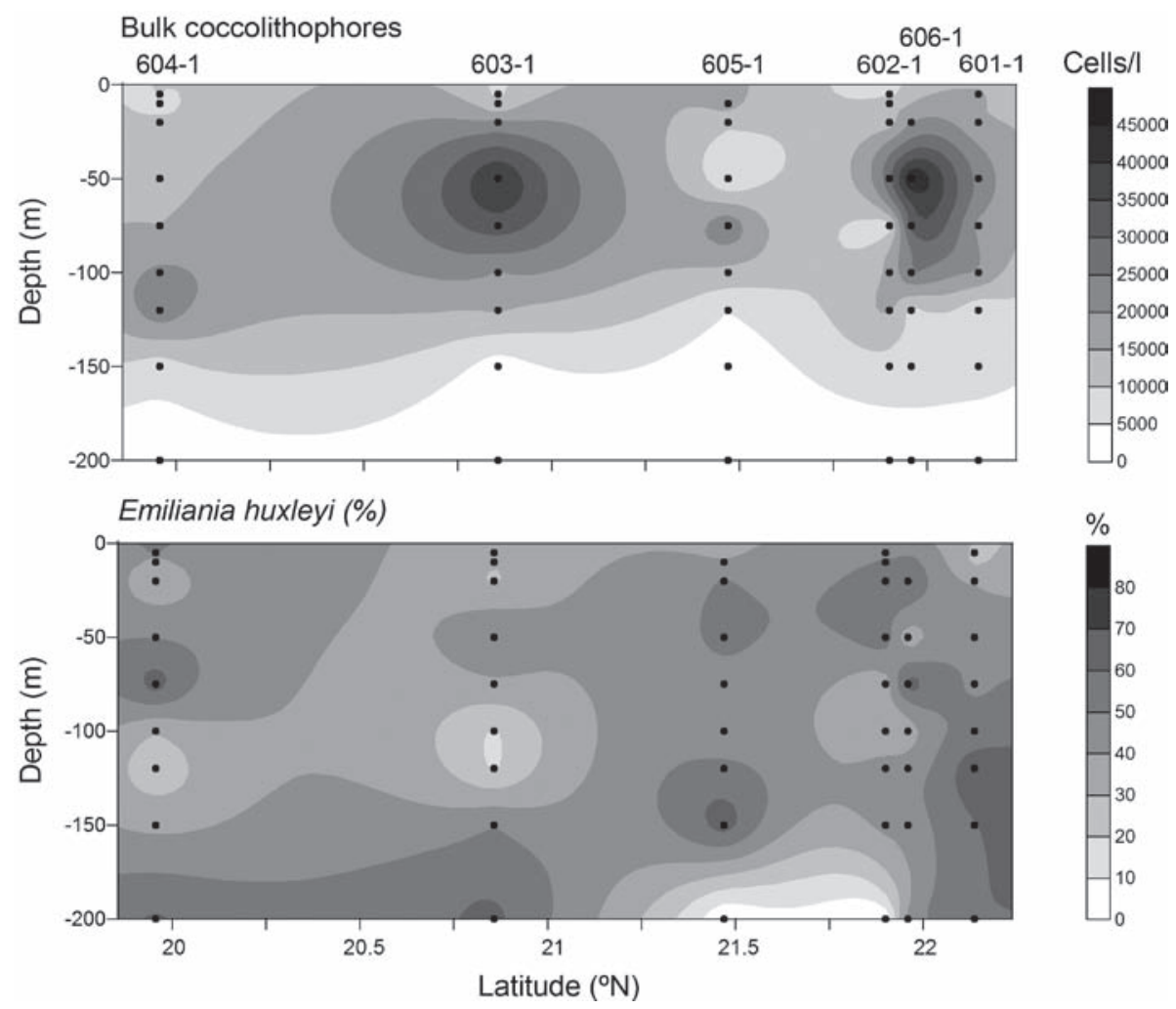

Fig. 3. Vertical distributions of total coccolithophorid cell numbers (above) as well as vertical distribution of the \%-abundances of Emiliania huxleyi (below) along the studied transect.

well as Gephyrocapsa oceanica and G. ericsonii. This species composition may indicate a less obvious middle photic zone (MPZ) assemblage.

The UPZ assemblage is characterized by Umbellosphaera tenuis (type IV) which is the most abundant species and can generally be recognized down to about $50 \mathrm{~m}$ water depth (Fig. 4). U. tenuis type IV was correlated to warm temperatures and low nutrient levels and a very deep nutricline by Boeckel \& Baumann (2008). Although morphologically and ecologically rather similar to type III, the distribution of type IV extends to deeper-water levels (Hagino \& Okada, 2006; Boeckel \& Baumann, 2008), which is rather consistent with the present observations. Other typical members of this UPZ assemblage are Discosphaera tubifera and Rhabdosphaera clavigera, as well as species of the family Syracosphaeraceae (e.g. S. pulchra), and most of the few holococcolithophore species observed. Discosphaera tubifera is reported to live in the upper to middle photic zone down to $40-80 \mathrm{~m}$ water depths in oligotrophic environments (e.g. Honjo \& Okada, 1974; Reid, 1980; Hagino et al., 2000; Malinverno et al., 2003; Boeckel \& Baumann, 2008), also rather consistent with our observations. The same pattern is displayed by Rhabdosphaera clavigera and Syracosphaera pulchra, all of which are non-placoliths known to prefer stable stratified waters (Okada \& McIntyre, 1977; Hagino et al., 2000). Of all species of the genus Syracosphaera observed, $S$. pulchra appears to have the greatest preference for warm, oligotrophic conditions. Thus, the composition of this assemblage is similar to those previously published as UPZ assemblages (e.g. Winter et al., 1994; Hagino et al., 2000; Kinkel et al., 2000;
Cortés et al., 2001; Malinverno et al., 2003; Andruleit, 2007) in terms of cell density and the dominance of typically non-placolith type species. In addition, the occurrence of species such as U. tenuis and D. tubifera underlines the influence of tropical and oligotrophic conditions. The low coccolithophore cell densities in the upper photic zone ( $<50 \mathrm{~m}$ water depth) may be explained by low nutrient concentrations during the sampling period.

Emiliania huxleyi is found in relatively low absolute cell numbers compared to much higher cell densities reported from the high-nutrient systems, but it is relatively common in rather equal percentages throughout the whole water column in the present samples (see Fig. 3). This species tolerates a wide temperature range, although its highest abundances usually occur at water temperatures of $<23{ }^{\circ} \mathrm{C}$ (Giraudeau \& Bailey, 1995; Haidar \& Thierstein, 2001; Hagino et al., 2005), and it is common under eutrophic as well as oligotrophic conditions. E. huxleyi consists of at least four well-established morphological groups (Young et al., 2003), of which only the type A form (i.e. the 'warm water' type of McIntyre \& Bé, 1967; Hagino et al., 2005) was found in the present samples. Its increased cell numbers in middepths may be due to the influence of the coastal upwelling on the Yucatan margin through offshore migration of nutrientenriched filaments. Other placolith-bearing species, such as Gephyrocapsa ericsonii, Calcidiscus leptoporus or species of Umbilicosphaera, have also been regarded in previous investigations as species adapted to rather low nutrient levels (Okada \& Honjo, 1975; Okada \& McIntyre, 1977; Giraudeau, 1992; Baumann et al., 2008). Some of these species, particularly Gephyrocapsa 

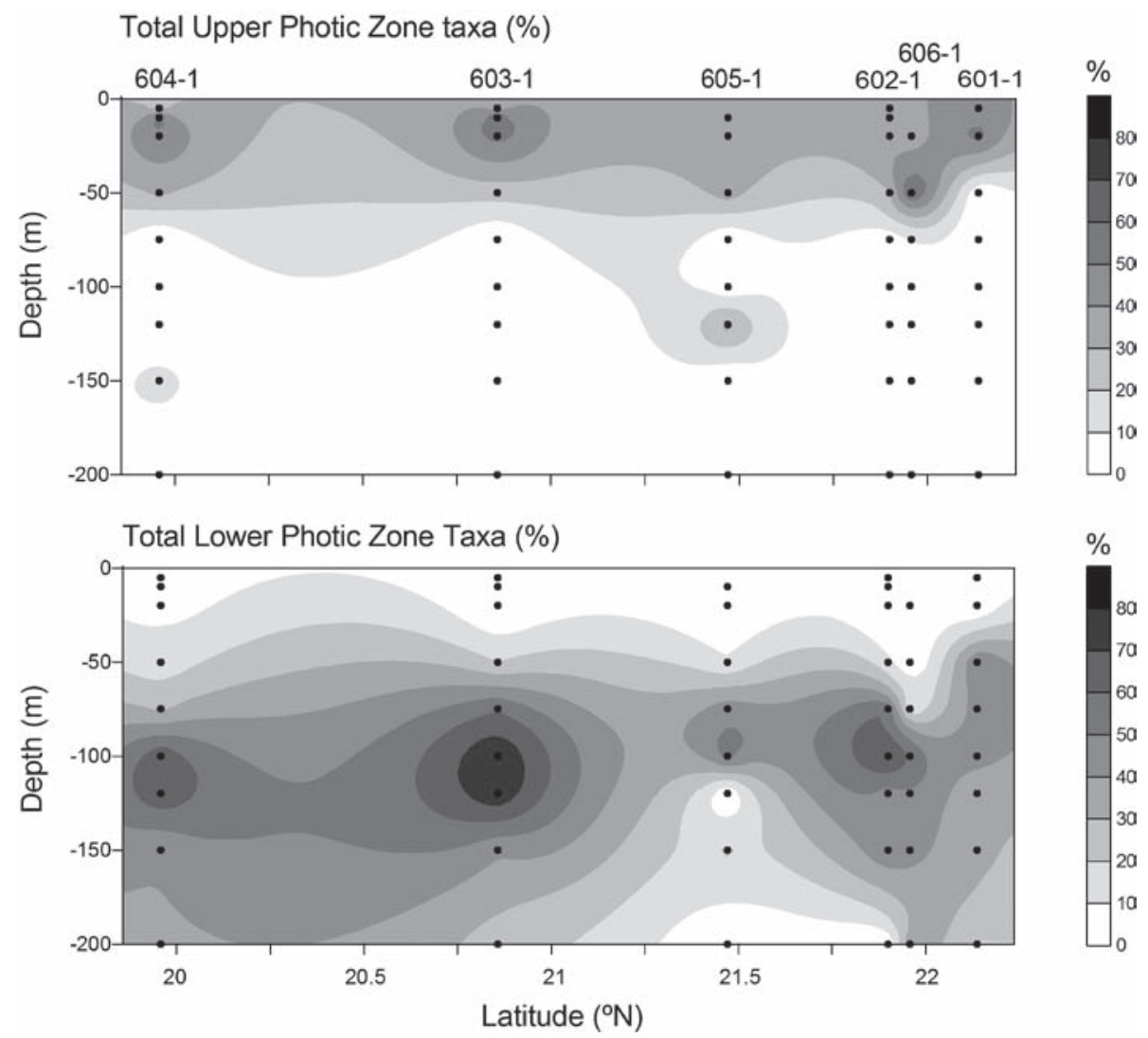

Fig. 4. Vertical distributions both of the total UPZ taxa (above) and of the total LPZ taxa (below) along the studied transect.

oceanica and G. ericsonii, are also known to occupy the intermediate water depth, and were termed MPZ assemblages, which usually were found at $80-120 \mathrm{~m}$ of water depth (Jordan \& Chamberlain, 1997). Coccolithophores, such as E. huxleyi and $G$. oceanica tend to live at greater depths in the central gyres because of the input of nutrients at these depths (Brand, 1994). Nevertheless, the depth range of these species may vary due to changing environmental conditions during different seasons of a year, when surface-water stratification may be more pronounced (Reid, 1980; Jordan \& Chamberlain, 1997).

Most of the LPZ dwellers are abundant in tropical to subtropical regions, as was commonly observed (e.g. Hagino et al., 2000; Andruleit, 2007; Boeckel \& Baumann, 2008). In particular, F. profunda is well known as an LPZ species (Jordan \& Chamberlain, 1997) and also dominates the samples studied in the southwestern GoM. This species typically occurs at maximum abundances below the deep chlorophyll maximum (40-200 m), in relatively high abundances even under relatively low nutrient conditions (Haidar \& Thierstein, 2001). As reported previously (e.g. Jordan \& Chamberlain, 1997; Hagino et al., 2000; Malinverno et al., 2003), other species, such as Gladiolithus flabellatus and Algirosphaera robusta, are also mainly restricted to the lower photic zone. In addition, highest concentrations of coccolithophores were already observed at the thermocline depth in wellstratified waters (e.g. Hagino et al., 2000). The upper or lower vertical distribution limits of many coccolithophore taxa coincides with the top of the thermocline. The assemblage in the deep photic zone ( $>50 \mathrm{~m}$ water depth; Fig. 4 ) is composed mainly of abundant Florisphaera profunda, Gladiolithus flabellatus and Algirosphaera robusta, indicating a tolerance of lower light availability. Thus, all these LPZ species may be typical for oligotrophic and stable conditions in open ocean waters.

\section{Comparison with previous plankton observations}

For the comparison of the present coccolithophore assemblages with assemblages previously observed in the area in October 1990 and March 1991 (Pariente, 1997), a 'mean plankton community' was calculated from all plankton samples by taking the average abundance (weighted by the absolute numbers) of the dominant species (Fig. 5). The assemblages found in October 1990 outside a warm-core eddy that moved west across the gulf (the so-called Quiet Eddy) in the northern GoM were also depth stratified, rather similarly to the present findings. The absolute coccolithophore cell numbers also were quite similar. However, in contrast to the present study, cells in the upper water layer belonged mainly to the species Umbellosphaera irregularis, while the dominant species at mid-depths was Umbellosphaera tenuis and in the lower photic zone it was Florisphaera profunda (Fig. 5). Other species were less common, while Emilania huxleyi was common throughout the water column, as it is in the present samples. However, absolute cell numbers as well as relative abundances of E. huxleyi were rather higher in the present samples than observed by Pariente (1997). In contrast, F. profunda obviously occurred in much lower numbers in March 2006.

The conspicuous difference in the relative composition of the UPZ assemblages is rather surprising, since $U$. irregularis has also 

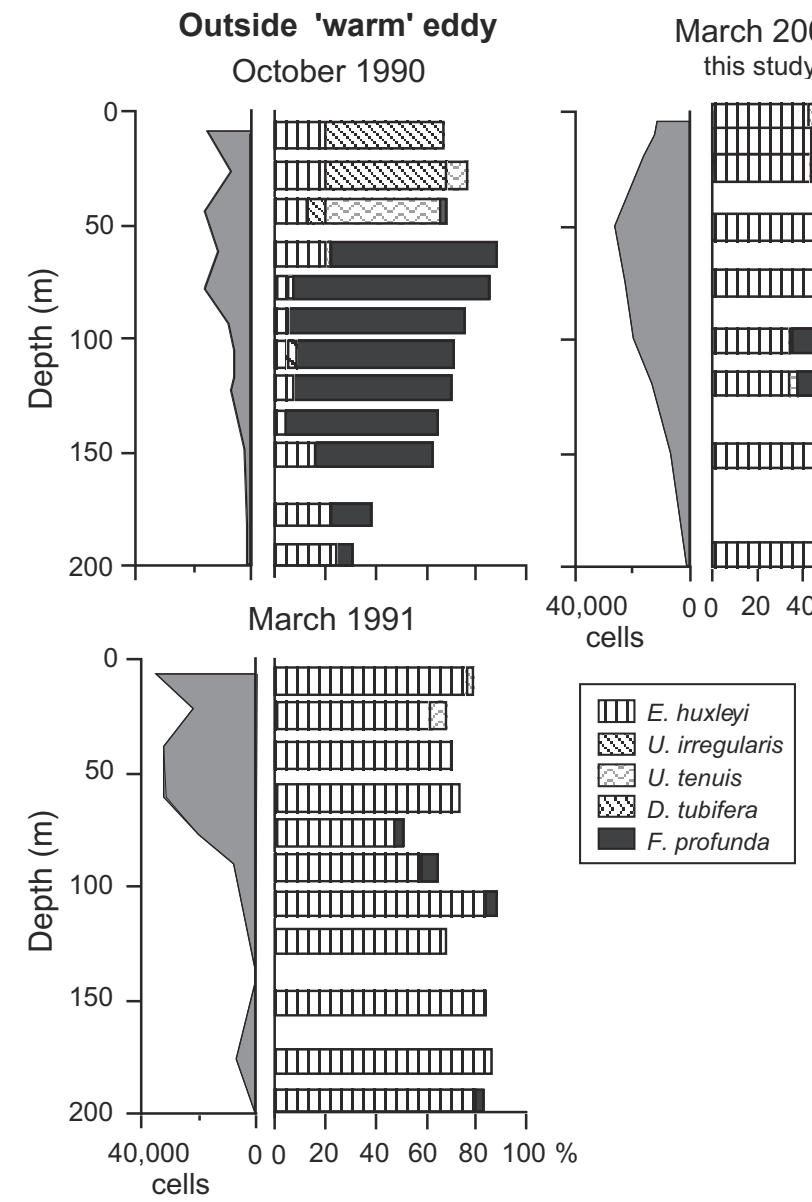

Inside 'warm' eddy

October 1990

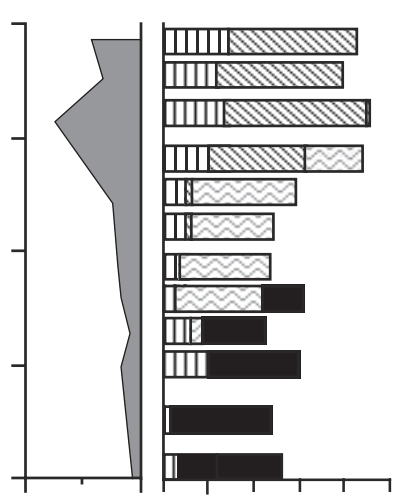

March 1991

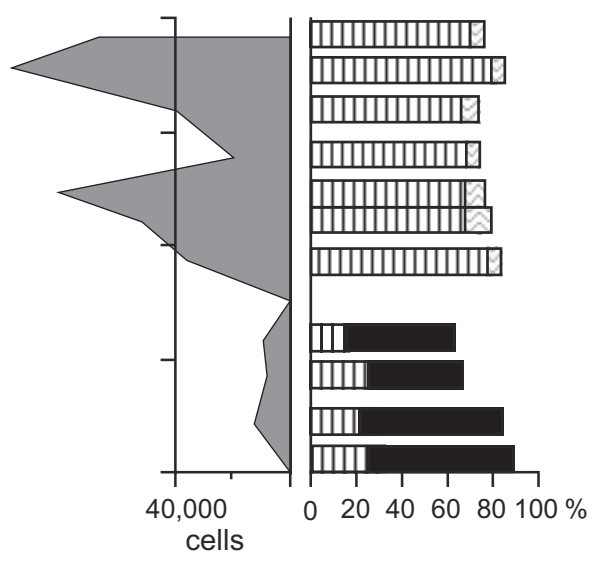

Fig. 5. Comparison of the present coccolithophore assemblages sampled in March 2006 (this study) with assemblages previously observed in the area in October 1990 and March 1991 (Pariente, 1997). A 'mean plankton community' was calculated from all plankton samples by taking the average abundance (weighted by the absolute numbers) of the dominant species.

been reported as a typical member of oligotrophic surface waters (e.g. Haidar \& Thierstein, 2001; Hagino \& Okada, 2004, 2006; Boeckel \& Baumann, 2008; Baumann et al., 2008). This species has been found both at stations with extremely high temperatures $\left(>30^{\circ} \mathrm{C}\right)$ and high nutrient levels (Hagino et al., 2000) as well as in the usual warm oligotrophic environments. However, Hagino \& Okada (2006) also showed that this species was absent when phosphate concentration was relatively high. Thus, it could be speculated that slight input of nutrients may be responsible for $U$. irregularis not occurring in these samples. This may suggest that the phosphate 'threshold' was possibly reached at the studied stations. Thus, the main outline when comparing the assemblages of October 1990 with those of March 2006 is similar, but discrepancies are obvious.

Even more striking, however, are the discrepancies when comparing the two March assemblages. The coccolithophore assemblages found in March 1991 are completely different to those in the present samples (Fig. 5). No species was very numerous compared to $E$. huxleyi, which almost exclusively occurred throughout the water column. Pariente (1997) suggested the reason for the change in abundance and distribution of coccolithophore species from October to March is that, during winter, stronger mixing brings both nutrients and coccolithophores into the upper layers from deeper water. Species such as E. huxleyi that need more light and more nutrients are able to grow faster. In contrast, species that require higher temperatures suffer. Nevertheless, these ideas cannot explain the discrepancies observed for the two March assemblages. Thus, the assemblages observed in March 1991 may be influenced by additional nutrient supply most probably through offshore migration of nutrient-enriched filaments from the coastal upwelling on the Yucatan margin. Coccolithophores were much more abundant than in October, also especially within the eddy, due to a general increase in E. huxleyi. In addition, U. irregularis was missing in these samples, while low cell numbers of $U$. tenuis occurred in the upper photic zone and $F$. profunda was abundant inside the eddy (Pariente, 1997).

Thus, the present coccolithophore assemblage may represent a mean between two end-member assemblages depicted in October 1990 and March 1991. The overall coccolithophore cell concentrations did not vary much, but proportions of some species changed greatly. To what extent oil drops and oil slicks that were observed on the sea surface during Meteor cruise M67/2 (Bohrmann et al., 2008) may have influenced these assemblage compositions is difficult to assess. Coccolithophorid assemblages may be sufficient to allow effects of pollution to be detected in the open marine realm. However, sustained observations over multiple years are required to assess direct and indirect impacts of oil and dispersants on the marine pelagic ecosystem in the GoM. 
First data, using satellite measurements, numerical circulation models and other environmental data, already give some initial results on observed biological changes at the base of the food web after the Deepwater Horizon oil spill (Hu et al., 2011). However, the available data are still insufficient to support or reject a hypothesis that the subsurface oil may have contributed to the enhanced biomass during December 2010 and January 2011.

\section{SUMMARY AND CONCLUSIONS}

The present study was conducted to provide information about coccolithophore standing stock and coccolithophore species composition in the southwestern GoM. Based on our data the following conclusions can be drawn:

(1) A total of 39 species were observed in the samples of the southwestern GoM, from which only eight species contributed significantly to the species community. Emiliania huxleyi was the numerically most abundant species in most of the samples, demonstrated a wide range of living depths, but only reached relatively low cell numbers $(<25000$ cells $\left.1^{-1}\right)$. In addition, Umbellosphaera tenuis and Florisphaera profunda were observed in comparable cell numbers.

(2) A distinct vertical stratification in the coccolithophorid assemblage was observed. The UPZ assemblage can be recognized generally down to about $50 \mathrm{~m}$ water depth and is characterized by highest cell numbers of Umbellosphaera tenuis (type IV). Other typical members of this group are Discosphaera tubifera and Rhabdosphaera clavigera, as well as many of the species of the family Syracosphaeraceae.

(3) The flora in the deep photic zone $(>50-100 \mathrm{~m}$ water depth) is characterized by abundant Florisphaera profunda, Gladiolithus flabellatus and Rhabdosphaera clavigera, indicating a tolerance of lower light availability.

(4) In the study area, the vertical distribution of most coccolithophore taxa was controlled by upper photic-zone temperature and water stratification. The coccolithophore communities, therefore, mainly reflected the local oceanographic situation and seemed to be more dependent on mixed layer depth and nutrient availability than on temperature and salinity changes.

(5) When comparing the presently observed coccolithophore assemblage with assemblages sampled in October 1990 the main pattern may be similar, but discrepancies are obvious. The overall coccolithophore cell concentrations did not vary much, but proportions of some species changed a lot. However, even more striking are the discrepancies when comparing the present findings with coccolithophore assemblages found in March 1991. The latter were completely different to those in the present samples. No species was very numerous compared to E. huxleyi, which occurred almost exclusively throughout the water column.

\section{ACKNOWLEDGEMENTS}

We are grateful to the officers and crew of the research vessel Meteor and to the scientific crew of Meteor cruise M67/2a for their help in retrieving the samples. The laboratory assistance of
Katharina Kubzda and Mariem Saavedra Pellitiero is gratefully acknowledged. We also thank Lluisa Cros, an anonymous reviewer, and the associate editor Jeremy Young for helpful comments and suggestions that have greatly improved the manuscript. This research was funded by the Deutsche Forschungsgemeinschaft (Research grant Ba 1648/17) while the Meteor M67/2 cruise was funded through DFG-Research Center/Cluster of Excellence 'The Ocean in the Earth System'. All data have been submitted to the Publishing Network for Geoscientific \& Environmental Data (PANGAEA, www.pangaea.de).

\section{Manuscript received 28 April 2011 \\ Manuscript accepted 8 October 2012 \\ Scientific Editing by Jeremy Young}

\section{APPENDIX A. TAXONOMIC LIST}

The taxonomic list includes all taxa identified during the present investigation. Identification generally followed Young et al. (2003), in which full references can be found. HOL, holococcolith.

Algirosphaera robusta (Lohmann, 1902) Norris, 1984

Alisphaera unicornis Okada \& McIntyre, 1977

Calcidiscus leptoporus (Murray \& Blackman, 1898) Loeblich \& Tappan, 1978 ssp. leptoporus

Calyptrolithina multipora (Gaarder in Heimdal \& Gaarder, 1980) Norris, 1985

Coronosphaera maxima (Halldal \& Markali, 1955) Gaarder in Gaarder \& Heimdal, 1977

Coronosphaera mediterranea (Lohmann, 1902) Gaarder in Gaarder \& Heimdal, 1977

Cyrtosphaera aculeata (Kamptner, 1941) Kleijne, 1992

Discosphaera tubifera (Murray \& Blackman, 1898) Ostenfeld, 1900

Emiliania huxleyi (Lohmann, 1902) Hay \& Mohler, 1967

Florisphaera profunda Okada \& Honjo, 1973

Gephyrocapsa ericsonii McIntyre \& Bé, 1967

Gephyrocapsa oceanica Kamptner, 1943

Gladiolithus flabellatus (Halldal \& Markali, 1955) Jordan \& Chamberlain, 1993

Hayaster perplexus (Bramlette \& Riedel, 1954) Bukry, 1973

Helicosphaera carteri (Wallich, 1877) Kamptner, 1954

Helicosphaera carteri HOL (= Syracolithus catilliferus (Kamptner, 1937) Deflandre, 1952)

Michaelsarsia elegans Gran, 1912 emend. Manton et al., 1984

Ophiaster formosus Gran, 1912 emend. Manton \& Oates, 1983

Ophiaster hydroideus (Lohmann, 1903) Lohmann, 1913 emend. Manton \& Oates, 1983

Rhabdosphaera clavigera Murray \& Blackman, 1898

Reticulofenestra sessilis (Lohmann, 1912) Jordan \& Young, 1990

Scyphosphaera apsteinii Lohmann, 1902

Syracolithus ponticuliferus (Kamptner, 1941) Kleijne \& Jordan, 1990

Syracosphaera anthos (Lohmann, 1912) Janin, 1987

Syracosphaera anthos HOL $=$ (Periphyllophora mirabilis (Schiller, 1925) Kamptner, 1937) 
Syracosphaera halldalii Gaarder in Gaarder \& Hasle, 1971 ex Jordan \& Green, 1994

Syracosphaera histrica Kamptner, 19541

Syracosphaera lamina Lecal-Schlauder, 1951

Syracosphaera molischii Schiller, 1925 (type 3)

Syracosphaera ossa (Lecal, 1966) Loeblich \& Tappan, 1968 (type 2)

Syracosphaera pulchra Lohmann, 1902

Syracosphaera pulchra HOL oblonga type (= Calyptrosphaera oblonga Lohmann, 1902)

Syracosphaera tumularis Sánchez-Suárez, 1990

Umbellosphaera irregularis Paasche in Markali \& Paasche, 1955

Umbellosphaera tenuis (Kamptner, 1937) Paasche in Markali

\& Paasche, 1955 (types I \& IV)

Umbilicosphaera anulus (Lecal, 1967) Young \& Geisen in

Young et al., 2003

Umbilicosphaera foliosa (Kamptner, 1963, ex Kleijne, 1993)

Geisen in Sáez et al., 2003

Umbilicosphaera hulburtiana Gaarder, 1970

Umbilicosphaera sibogae (Weber-van Bosse, 1901) Gaarder, 1970

\section{REFERENCES}

Andruleit, H. 2007. Status of the Java upwelling area (Indian Ocean) during the oligotrophic northern hemisphere winter monsoon season as revealed by coccolithophores. Marine Micropaleontology, 64: 36-51.

Andruleit, H., Stäger, S., Rogalla, U. \& Cepek, P. 2003. Living coccolithophores in the northern Arabian Sea: Ecological tolerance and environmental control. Marine Micropaleontology, 49: 157-181.

Baumann, K.-H., Böckel, B. \& Cepek, M. 2008. Spatial distribution of living coccolithophores on an East-West transect in the subtropical South Atlantic. Journal of Nannoplankton Research, 30: 9-21.

Biggs, D.C. \& Müller-Karger, F.E. 1994. Hip and satellite observations of chlorophyll stocks in interacting cyclone-anticyclone eddy pairs in the western Gulf of Mexico. Journal of Geophysical Research, 99: 7371-7384.

Boeckel, B. \& Baumann, K.-H. 2008. Vertical and lateral variations in coccolithophore community structure across the subtropical frontal zone in the South Atlantic Ocean. Marine Micropaleontology, 67: 255-273.

Bohrmann, G., Spiess, V. \& cruise participants 2008. Report and Preliminary Results of R/V Meteor Cruise M67/2a and 2b, BalboaTampico-Bridgetown, 15 March-24 April, 2006. Fluid seepage in the Gulf of Mexico. Berichte Fachbereich Geowissenschaften, Universität Bremen, 263: 161.

Brand, L.E. 1994. Physiological ecology of marine coccolithophores. In Winter, A. \& Siesser, W.G. (Eds) Coccolithophores. Cambridge University Press, Cambridge, 39-49.

Brunner, C.A. 1982. Paleoceanography of surface waters in the Gulf of Mexico during the late Quaternary. Quaternary Research, 17: 105-119.

Cortés, M.Y., Bollmann, J. \& Thierstein, H.R. 2001. Coccolithophore ecology at the HOT station ALOHA, Hawaii. Deep-Sea Research II, 48: 1957-1981.

Dagg, M.J. 1995. Copepod grazing and the fate of phytoplankton in the northern Gulf of Mexico. Continental Shelf Research, 15: 1303-1317.

Gaarder, K.R. \& Hasle, G.R. 1971. Coccolithophorids of the Gulf of Mexico. Bulletin of Marine Science, 21: 519-544.

Giraudeau, J. 1992. Distribution of recent nannofossils beneath the Benguela system: southwest African continental margin. Marine Geology, 108: 219-237.
Giraudeau, J. \& Bailey, G.W. 1995. Spatial dynamics of coccolithophore communities during an upwelling event in the Southern Benguela system. Continental Shelf Research, 15: 1825-1852.

Gyory, J., Mariano, A.J. \& Ryan, E.H. n.d. The Yucatan Current. In Ocean Surface Currents. http://oceancurrents.rsmas.miami.edu/caribbean/ yucatan.html (accessed 17 May 2013).

Hagino, K. \& Okada, H. 2004. Floral response of coccolithophores to progressive oligotrophication in the South Equatorial Current, Pacific Ocean. In Shiyomi, M. et al. (Eds), Global Environmental Change in the Ocean and on Land. Terrapub, Tokyo, 121-132.

Hagino, K. \& Okada, H. 2006. Intra- and infra-specific morphological variation in selected coccolithophore species in the equatorial and subequatorial Pacific Ocean. Marine Micropaleontology, 58: 184-206.

Hagino, K., Okada, H. \& Matsuoka, H. 2000. Spatial dynamics of coccolithophore assemblages in the equatorial western-central Pacific Ocean. Marine Micropaleontology, 39: 53-57.

Hagino, K., Okada, H. \& Matsuoka, H. 2005. Coccolithophore assemblages and morphotypes of Emiliania huxleyi in the boundary zone between the cold Oyashio and warm Kuroshio currents off the coast of Japan. Marine Micropaleontology, 55: 19-47.

Haidar, A.T. \& Thierstein, H.R. 2001. Coccolithophore dynamics off Bermuda (N. Atlantic). Deep-Sea Research II, 48: 1925-1956.

Hernández-Becerril, D.U. \& Flores, C. 1998. Species of the diatom genus Chaetoceras (Bacillariophyceae) in the plankton from the southern Gulf of Mexico. Botanica Marina, 41: 505-519.

Hernández-Becerril, D.U., García-Reséndiz, J.A., Salas-de León, D.A., Monreal-Gómez, M.A., Signoret-Poillon, M. \& Aldeco-Ramírez, J. 2008. Nanoplankton fraction in the phytoplankton structure in the southern Gulf of Mexico (April 2000). Ciencias Marinas, 34: 77-90.

Honjo, S. \& Okada, H. 1974. Community structure of coccolithophores in the photic layer of the mid-Pacific. Micropaleontology, 29: 209-230.

Hu, C., Weisberg, R.H., Liu, Y. et al. 2011. Did the northeastern Gulf of Mexico become greener after the Deepwater Horizon oil spill? Geophysical Research Letters, 38: 109601, http://dx.doi.org/10.1029/2011GL047184.

Hulburt, E.M. \& Corwin, N. 1972. A note on the phytoplankton distribution in the offshore waters of the eastern and central Gulf of Mexico. Caribbean Journal of Science, 12, 29-38.

Johns, W.E., Townsend, T.L., Fratantoni, D.M. \& Wilson, W.D. 2002. On the Atlantic inflow to the Caribbean Sea. Deep-Sea Research, 49: 211-243.

Jordan, R.W. \& Chamberlain, A.H.L. 1997. Biodiversity among haptophyte algae. Biodiversity Conservation, 6: 131-152.

Kinkel, H., Baumann, K.-H. \& Cepek, M. 2000. Coccolithophores in the equatorial Atlantic Ocean: Response to seasonal and Late Quaternary surface water variability. Marine Micropaleontology, 39: 87-112.

Klapp, S.A., Murshed, M.M., Pape, T. et al. 2010. Mixed gas hydrate structures at the Chapopote Knoll, southern Gulf of Mexico. Earth and Planetary Science Letters, 299: 207-217.

Lee, T.N. \& Mayer, D.A. 1977. Low frequency current variability and spinoff eddies on the shelf off southeast Florida. Journal of Marine Research, 35: 193-220.

Licea, S., Zamudio, M.E., Luna, R. \& Soto, J. 2004. Free-living dinoflagellates in the southern Gulf of Mexico: Report of data (1979-2002). Phycological Research, 52, 419-428.

Livingston, R.J. 2007. Phytoplankton bloom effects on a Gulf estuary: water quality changes and biological response. Ecological Applications, 17(Suppl.): S110-S128.

Lohrenz, S.E., Dagg, M.J. \& Whitledge, T.E. 1990. Enhanced primary production at the plume/oceanic interface of the Mississippi River. Continental Shelf Research, 10, 639-664.

Macdonald, I.R., Bohrmann, G., Escobar, E. et al. 2004. Asphalt volcanism and chemosynthetic life in the Campeche Knolls, Gulf of Mexico. Science, 304(5673): 999-1002.

Malinverno, E., Ziveri, P. \& Corselli, C. 2003. Coccolithophorid distribution in the Ionian Sea and its relationship to eastern Mediterranean 
circulation during late fall to early winter 1997. Journal of Geophysical Research, 108: 8115, http://dx.doi.org/10.1029/2002JC001346.

McIntyre, A. \& Bé, A.W.H. 1967. Modern coccolithophoridae of the Atlantic Ocean - I. Placoliths and Cyrtoliths. Deep-Sea Research, 14: 561-597.

Merino, M. 1997. Upwelling on the Yucatan Shelf: Hydrographic evidence. Journal of Marine Systems, 13: 101-121.

Molinari, R.L. \& Morrison, J. 1988. The separation of the Yucatan Current from the Campeche Bank and the intrusion of the Loop Current into the Gulf of Mexico. Journal of Geophysical Research, 93: 10,645-10,654.

Molinari, R.L., Johns, E. \& Festa, J.F. 1990. The annual cycle of meridional heat-flux in the Atlantic Ocean at $26.5^{\circ} \mathrm{N}$. Journal of Physical Oceanography, 20: 476-482.

Müller-Karger, F.E., Walsh, J.J., Evans, R.H. \& Meyers, M.B. 1991. On the seasonal phytoplankton concentration and sea surface temperature cycles of the Gulf of Mexico as determined by satellites. Journal of Geophysical Research, 96: 12,645-12,665.

Ochoa, J., Sheinbaum, H., Badan, A., Candela, J. \& Wilson, D. 2001. Geostrophy via potential vorticity inversion in the Yucatan Channel. Journal of Marine Research, 59: 725-747.

Okada, H. \& Honjo, S. 1975. Distribution of coccolithophores in marginal seas along the western Pacific Ocean and in the Red Sea. Marine Biology, 31: 271-285.

Okada, H. \& McIntyre, A. 1977. Modern coccolithophores of the Pacific and North Atlantic Oceans. Micropaleontology, 23: 1-55.

Okolodkov, Y.B. 2003. A review of Russian plankton research in the Gulf of Mexico in the 1960-1980s. Hidrobiologica, 13: 207-221.

Ortner, P.B., Ferguson, R.L., Piotrowicz, S.R., Chesal, L., Berberian, G.A. \& Palumbo, A.V. 1984. Biological consequences of hydrographic and atmospheric advection within the Gulf Loop Intrusion. Deep-Sea Research, 31: 1101-1120.
Pariente, V. 1997. Coccolithophores - At home in the Gulf of Mexico. Quaterdeck Online, 5, http://ocean.tamu.edu/Quarterdeck/QD5.2/ qdhome-5.2.html (accessed 17 May 2013).

Reid, F.M.H. 1980. Coccolithophorids from the North Pacific central gyre with notes on their vertical and seasonal distribution. Micropaleontology, 26: $151-176$.

Sheinbaum, J., Candela, J., Badan, A. \& Ochoa, J. 2002. Flow structure and transport in the Yucatan Channel. Geophysical Research Letters, 29: 10-1-10-4.

Strom, L.S. \& Strom, M.W. 1996. Microplankton growth, grazing, and community structure in the northern Gulf of Mexico. Marine Ecology Progress Series, 130: 229-240.

Sturges, W. \& Evans, J.C. 1983. On the variability of the Loop Current in the Gulf of Mexico. Journal of Marine Research, 41: 639-653.

Sturges, W. \& Leben, R. 2000. Frequency of ring separations from the Loop Current in the Gulf of Mexico: A revised estimate. Journal of Physical Oceanography, 30: 1814-1819.

Sturges, W. \& Lugo-Fernandez, A. 2005. Circulation in the Gulf of Mexico: Observations and Models. Monograph 161, American Geophysical Union, 360pp. + CD appendix.

Vidal, V.M.V., Vidal, F.V., Hernámdez, A.F., Meza, E. \& Zambrano, L. 1994. Winter water mass distributions in the western Gulf of Mexico affected by a colliding anticyclonic ring. Journal of Oceanography, 50: 559-588.

Winter, A., Jordan, R.W. \& Roth, P.H. 1994. Biogeography of living coccolithophores. In Winter, A. \& Siesser, W.G. (Eds), Coccolithophores. Cambridge University Press, New York, 161-178.

Young, J.R., Geisen, M., Cros, L. et al. 2003. A guide to extant coccolithophore taxonomy. Journal of Nannoplankton Research, Special Issue, 1: 125pp.

Zavala-Hidalgo, J., Morey, S.L., O’Brien, J.J. \& Zamudio, L. 2006. On the Loop Current eddy shedding variability. Atmosfera, 19: 41-48. 
The

Geological

Society

serving science $\mathcal{E}$ profession
Map Reproduction from the Geological Society

The Geological Society is proud to offer a stunning range of historical reproduction maps available to buy from our outstanding map collection.

Around 100 maps are currently available, with the collection continuing to grow. The current collection includes William Smith sections and coverage of Europe, India, North America, Australia and New Zealand. Printed on high quality paper, the maps are perfect for research or to frame.

If you would like a print of a map in our collection that is not currently available, it may also be possible to arrange scanning and copying of the map provided it is out of copyright.

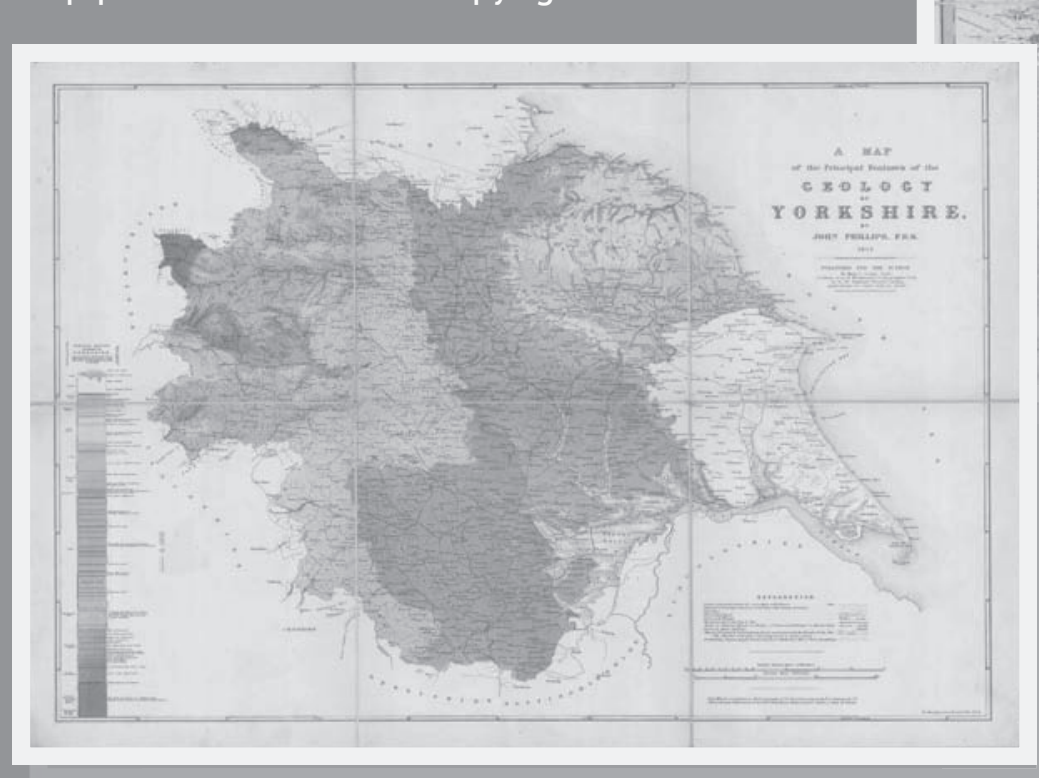

Fellows: each sheet costs $£ 25$ + VAT and postage Non-Fellows: each sheet costs $£ 35+$ VAT and postage

Explore our collection online: www.geolsoc.org.uk/mapsale

\section{How much} does this cost? 